\title{
PENGARUH PROMOSI PENJUALAN PAKAIAN TERHADAP MINAT BELI PADA TOKO ZOYA JAMBI
}

\author{
Agesha Marsyaf \\ Dosen Tetap Universitas Muhammadiyah Jambi \\ Agesha.marsyaf.am@gmail.com
}

Ringkasan

Pada dasarnya setiap konsumen memiliki berbagai macam faktor yang mempengaruhi dalam berprilaku, salah satunya adalah minat terhadap berbagai produk termasuk produk busana atau pakaian muslim. Prilaku konsumen sangat berkaitan erat dengan sikap konsumen terhadap produkbusana muslim, sikap terhadap prilaku dimana seseorang melakukan penilaian atas sesuatu yang menguntungkan dan tidak menguntungkan. Konsep sikap sangat berkaitan erat dengan kepercayaan istilah ini membentuk sikap konsumen seringkali menggambarkan hubungan antara kepercayaan, sikap dan perilaku konsumen

Hasil hitungan regresi sederhana untuk Promosi menunjukan bahwa Promosi mempunyai pengaruh yang Positif dan Signifikan, dengan nilai Koefisien regresi sebesar 0,620 dengan tingkat signifikansi sebesar 0,005, artinya variabel independen pada penelitian ini yaitu promosi berpengaruh terhadap variabel dependen yang dalam hal ini adalah minat beli

Kata Kunci: Promosi, Penjualan, Minat beli

\section{PENDAHULUAN}

Dalam memasuki era globalisasi ini, dimana kegiatan bisnis diwarnai dengan intensitas persaingan yang semakin tinggi antara perusahaan satu dengan perusahaan lainnya. Terlebih lagi bagi perusahaan yang menghasilkan produk yang sejenis dimana para perusahaan tentu berusaha secara maksimal untuk dapat memenuhi kebutuhan dan keinginan konsumen. Jadi, jika perusahaan tanggap dan mampu mengerti kondisi pasar sehingga dapat menguasai pasar untuk bertahan diarena persaingan yang semakin tinggi, sehingga perusahaan dapat memenangkan persaingan.

Selain itu cara yang dilakukan dengan meningkatkan kegiatan pemasaran Antara promosi dan produk, tidak dapat dipisahkan, dua hal ini yang saling berkaitan untuk menuju suksesnya pemasaran. Di sini harus ada keseimbangan, produk baik, sesuai dengan selera konsumen, dibarengi dengan teknik promosi yang tepat akan sangat membantu suksesnya usaha marketing.

Teknik promosi yang digunakan ketika melakukan kegiatan promosi penjualan di Toko Zoya Jambi, yaitu dengan sering update status yang isinya menawarkan keunggulan kualitas produk yang dijual, share picture membuat tampilan produk yang menarik seperti menggunakan background foto yang menarik. Kegiatan promosi merupakan salah satu usaha 
perusahaan untuk meningkatkan penjualan pada produknya, sebuah perusahaan perlu menentukan kebijakan yang baik dalam melakukan kegiatan promosi, sebab promosi akan menciptakan sebuah komunikasi dengan konsumen. Jika promosi yang di sampaikan kepada konsumen mendapatkan respon positif maka dapat meningkatkan penjualan produk yang dipromosikan oleh perusahaan.

Salah satunya promosi penjualan yang dipilih oleh toko Zoya Jambi untuk mengembangkan dalam dunia bisnis, dilihat dalam persaingan bisnis yang semangkin banyak bermunculan, sistem promosi penjualan yang dipilih oleh toko zoya Jambi ini untuk lebih menarik konsumen ketepatan perusahaan dalam memilih promosi penjualan sebagai salah satu promosi akan sangat berpengaruh terhadap tingkat penjualan produk yang ditawarkan oleh perusahaan, karena dalam hal ini tugas dari promosi penjualan adalah menawarkan, memperkenalkan produk yang akan dipasarkan. Untuk melihat besaran pengeluaran promosi penjualan toko Zoya Jambi dapat dilihat pada tabel dibawah ini.

Tabel 1.1

Biaya Pomosi Toko Zoya Jambi 2017-2019

\begin{tabular}{|c|c|}
\hline Tahun & $\begin{array}{c}\text { Biaya Promosi } \\
\text { (Rupiah) }\end{array}$ \\
\hline 2017 & $2,420,000$ \\
\hline 2018 & $2,856,000$ \\
\hline 2019 & $3,871,000$ \\
\hline
\end{tabular}

Sumber: Toko Zoya Kota Jambi, 2019

Jilbab Zoya memperoleh penghargaan Indonesia Middle-class moslem brand champion consumers' choice pada tahun 2014 berdasarkan riset yang dilakukan oleh majalah bisnis SWA, jilbab zoya menjadi merek pilihan konsumen kelas menengah. Penghargaan top Brand 2015 yang diterima zoya didasari oleh survey dan penelitian yang diselenggarakan oleh majalah marketing dan frontier consulting group. Top brand award diukur dengan tiga parameter, yaitu top of mind share, top of market share, dan top of commitment share yang telah diraih zoya sebagai kerudung bermerek pilihan konsumen Indonesia berdasarkan hasil riset MARS Indonesia, majalah SWA dan Metro TV. Zoya kembali mendapatkan penghargaan top brand award 2016 serta best brand award 2016 untuk kategori kerudung bermerek. Sebelumnya penghargaan berupa diraih Zoya di tahun 2015 yang berarti selama dua tahun berturut-turut mendapatkan kepercayaan dari masyarakat Indonesia. 


\section{TINJAUAN PUSTAKA}

Strategi pemasaran merupakan strategi untuk melayani pasar atau segmen pasar yang di jadikan target oleh perusahaan. Definisi strategi pemasaran adalah sebagai berikut: "strategi pemasaran adalah logika pemasaran yang digunakan oleh perusahaan dengan harapan agar unit bisnis dapat mencapai tujuan perusahaan "(Kotler, 2010). Merancang strategi pemasaran yang kompetitif dimulai dengan melakukan analisis terhadap pesaing. Perusahaan membandingkan nilai dan kepuasan pelanggan dengan nilai yang diberikan oleh produk, harga, promosi dan distribusi (marketing mix) terhadap pesaing dekatnya. Menurut Radiosunu (2012) strategi pemasaran didasarkan atas lima konsep strategi berikut:

a. Segmentasi pasar.

Tiap pasar terdiri dari bermacam-macam pembeli yang mempunyai kebutuhan, kebiasaan membeli dan reaksi yang berbeda-beda. Perusahaan tak mungkin dapat memenuhi kebutuhan semua pembeli. Karena itu perusahaan harus mengkelompokkelompokkan pasar yang bersifat heterogen ke dalam satuan-satuan pasar yang bersifat homogen

b. Market positioning.

Perusahaan tak mungkin dapat menguasai pasar keseluruhan. Maka prinsip strategi pemasaran kedua adalah memilih pola spesifik pemusatan pasar yang akan memberikan kesempatan maksimum kepada perusahaan untuk mendapatkan kedudukan yang kuat. Dengan kata lain perusahaan harus memilih segmen pasar yang dapat menghasilkan penjualan dan laba yang paling besar.

c. Targeting

Adalah strategi memasuki segmen pasar yang dijadikan sasaran penjualan.

d. Marketing mix strategy.

Kumpulan variabel-variabel yang dapat digunakan perusahaan untuk mempengaruhi tanggapan konsumen. Variabel-variabel yang dapat mempengaruhi pembeli adalah variabelvariabel yang berhubungan dengan product, place, promotion dan price (4P).

\section{Promosi (Promotion)}

Definisi promosi adalah usaha yang dilakukan pasar untuk mempengaruhi pihak lain agar berpartisipasi dalam kegiatan pertukaran (Kusmono, 2011). Menurut Basu Swasta (2010), promosi dipandang sebagai arus informasiatau persuasi satu arah yang dibuat untuk mengarahkan seseorang atau organisasi kepada tindakan yang menciptakan pertukaran dalam pemasaran. Promosi merupakan sarana yang paling ampuh untuk menarik 


dan mempertahankan konsumennya. Salah satu tujuan promosi perusahaan

adalah menginformasikan segala jenis produk yang ditawarkan dan berusaha menarik calon konsumen yang baru.

Paling tidaknya terdapat 4 macam saran promosi yang dapat digunakan oleh setiap perusahaan dalam mempromosikan produknya, baik barang maupun jasa. Keempat macam sarana yang digunakan adalah usaha perusahaan untuk mempengaruhi dengan merayu (persuasive communication) calon pembeli, melalui pemakaian segala unsur acuan pemasaran disebut promosi. Keempat unsur tersebut yaitu (Kasmir, 2010):

1. Periklanan (Advertising)

Iklan adalah sarana promosi yang digunakan oleh perusahaan guna menginformasikan, menarik, dan mempengaruhi calon pembelinya. Penggunaan promosi dengan iklan dapat dilakukan dengan berbagai media seperti lewat:

2. Promosi (Promotion)

Tujuan promosi penjualan adalah meningkatkan penjualan atau untuk meningkatkan jumlah pembeli. Promosi penjualan dilakukan untuk menarik pembeli agar segera membeli setiap produk atau jasa yang ditawarkan. Oleh karena itu, agar pembeli tertarik untuk membeli maka perlu dibuatkan promosi penjualan yang semenarik mungkin.

3. Publisitas (Publicity)

Publisitas merupakan kegiatan promosi untuk memancing pembeli melalui kegiatan seperti pameran, bakti sosial, serta kegiatan lainnya melalui berbagai media. Kegiatan publisitas dapat meningkatkan pamor perusahaan dimata para konsumennya, baik secara langsung maupun tidak langsung. Oleh karena itu, kegiatan publisitas perlu diperbanyak lagi.

4. Penjualan Pribadi (Personal Selling)

Personal selling, merupakan penyajian secara lisan dalam suatu pembicaraan dengan seseorang atau lebih calon pembeli dengan tujuan agar dapat terealisasinya penjualan. Di dalam perusahaan penjualan pribadi secara umum dilakukan oleh seluruh karyawan.

5. Pemasaran langsung (Direct marketing)

Hubungan langsung dengan konsumen individual yang ditargetkan secara cermat untuk memperoleh respons segera dan membangun hubungan pelanggan yang langgeng.

Bauran promosi ini digunakan untuk mengkomunikasikan kegiatan perusahaan kepada konsumen. Komunikasi yang efektif akan mengubah tingkah laku konsumen dan akan memperkuat tingkah laku yang telah diubah sebelumnya. 


\section{Minat Pembeli}

Menurut teori Keller dalam penelitian Dwiyanti, minat beli adalah "tahapan yang dilakukan oleh konsumen sebelum membeli, pengenalan masalah, pencarian informasi, dan seberapa besar kemungkinan konsumen yang melekat pada minat beli tersebut. Sedangkan menurut Kotler minat adalah suatu respon efektif atau proses merasa atau menyukai suatu produk tetapi belum melakukan keputusan untuk membeli. Terdapat tiga tahapan dalam menumbuhkan minat pembeli konsumen yaitu (Obama, 2019) :

a. Rangsangan, terjadi saat suatu keinginan mencapai daerah syaraf penerimaan indra seseorang.

b. Kesadaran, untuk dapat menjadi perhatian atas kesadaran seseorang maka rangsangan tersebut harus dapat mengetarkan syaraf indra dan yang menimbulkan respon langsung atau sensasi-sensasi pada otak. Misalnya ketika seseorang merasa tertarik untuk lebih mengetahui lebih jauh mengenai yang dilakukan perusahaan tersebut.

c. Pencarian informasi dibagi menjadi:

1) Informasi intern bersumber dari kegiatan konsumen untuk melebihi barang atau jasa yang memuaskannya.

2) Informasi ekstern informasi yang berasal dari iklan, melalui teman, ataupun dari media social.

3) Memastikan sifat yang khas dari setiap pilihan yang ada, pada tahap konsumen mengumpulkan informasi yang berhubungan dari ciri setiap pilihan, setelah itu baru konsumen memutuskan barang/jasa yang akan dibelinya.

4) Pemilihan alternatif, setelah informasi yang berkaitan dengan produk yang diinginkan telah diperoleh, maka konsumen melakukan penelitian akan alternative-alternatif yang ada yaitu : sifat produk (warna,ukuran,kemasan) misalnya konsumen akan membeli baju maka ia akan memperhatikan bahan, model, warna serta harganya.

\section{METODE PENELITIAN}

Penelitian yang dilakukan mengenai Pengaruh promosi penjualan pakaian terhadap minat Pembeli Pada Toko Zoya Jambi. Penelitian ini di lakukan di toko Zoya Jambi yang berlokasi di Jln. Basuki Rahmat no. 43 Jambi dan metode yang digunakan dalam penelitian ini menggunakan metode kuantitatif. Penelitian kuantitatif adalah penelitian yang menggunakan angka dalam penyajian data dan analisis yang menggunakan uji statistik. penelitian kuantitatif 
merupakan penelitian yang di perlu oleh hipotesis tertentu, yang salah satunya dari penelitian yang dilakukan adalah uji hipotesis yang di tentukan sebelumnya. Penelitian ini mengambil responden pada masyarakat atau konsumen toko Zoya Jambi.

\section{Populasi Dan Sampel}

Populasi adalah wilayah generalisasi yang terdiri atas objek/subjek yang mempunyai kualitas dan karakteristik tertentu yang ditetapkan oleh peneliti untuk dipelajari dan kemudian ditarik kesimpulan. Sampel adalah bagian dari jumlah dan karakteristik yang dimiliki oleh populasi tersebut (Sugiyono, 2016). Dengan demikian sampel adalah sebagian dari populasi yang karakteristiknya hendak diselidiki, dan bisa mewakili keseluruhan populasinya sehingga jumlahnya lebih sedikit dari populasi. Untuk penelitian ini diambil populasi sebesar 80 responden yang pernah berbelanja di toko Zoya Jambi.

Sampel merupakan bagian dari jumlah dan karakteristik yang dimiliki populasi tersebut (Sugiyono, 2016). Dalam penelitian ini menggunakan teknik Accidental sampling. Accidental sampling merupakan pengambilan sampel secara accidental dengan mengambil responden yang kebetulan ada disuatu tempat yang sesuai dengan tempat penelitian (Notoatmodjo, 2010). Sehingga dalam teknik accidental sampling ini peneliti mengambil responden pada saat itu juga di Toko Zoya Jambi. Penggunaan Accidental Sampling ini dikarenakan tidak semua konsumen yang datang ke Toko Zoya Jambi datang untuk membeli, sampel yang digunakan pada penelitian ini adalah sebanyak 80 responden.

\section{Metode Analisis Data}

Pengolahan data statistik dalam penelitian ini dengan menggunakan aplikasi program komputer atau software Statistical Product and Service Solution (SPSS) for Windows. Menurut Purnamasari (2010) sebelum melakukan pengolahan data statistik dengan SPSS for Windows, maka perlu dilakukan pengelompokan data sebagai tahap awal.

Penggunaan skala likert dengan alternatif skor nilai 1-5 untuk mengukur sikap, dan pendapat responden. Pendapat yang paling positif diberi skor 5 (maksimum), dan pendapat yang paling negatif diberi angka 1 (minimum). Dengan pertimbangan agar responden lebih mudah dalam menentukan pilihan jawaban, karena peneliti meyakini bahwa responden telah familiar dengan angka tersebut.

\section{Tabulating.}

Tabulating yaitu memasukkan data-data yang sudah dikelompokkan, kedalam tabel-tabel, agar mudah dibaca dan dipahami. 
Untuk rumusan masalah pertama digunakan analisis deskriptif, yang bertujuan untuk menggambarkan atau mendeskripsikan data yang diperoleh, analisis ini digunakan untuk menggambarkan secara lebih mendalam tentang karakteristik pembeli pada toko Zoya Kota Jambi

Untuk mendapatkan jawaban dari perumusan masalah kedua maka digunakan alat analisis regresi linier sederhana, dengan persamaan regresi linier sederhananya adalah sebagai berikut:

$\mathrm{Y}=\alpha+\beta_{1} X_{1}+\mathrm{e}$

Dimana

$\mathrm{Y}=$ Variabel Dependen (Minat Beli)

$X_{1}=$ Variabel Independen (Promosi Penjualan)

$\alpha=$ Konstanta

$\beta_{1}=$ Koefisien Regresi

e $=$ Variabel Lain Yang Tidak Diteliti Atau Dimasukan Dalam Model

\section{HASIL PENELITIAN}

Penelitian ini akan mendeskriptifkan data karakteristik responden berdasarkan jenis kelamin, usia, pendidikan terakhir, pekerjaan dan pendapatan. Analisis deskriptif digunakan untuk mengetahui tangggapan responden mengenai nilai variabel penelitian. Analisis deskriptif ditunjukkan melalui data presentase, seperti pada tabel-tabel dibawah ini

\section{A. Karakteristik Responden}

1) Karakteristik Responden Berdasarkan Jenis Kelamin

Tabel 5.1

Karakteristik Pembeli Berdasarkan Jenis Kelamin

\begin{tabular}{|l|c|c|}
\hline \multicolumn{1}{|c|}{ Jenis Kelamin } & Responden & $\begin{array}{c}\text { Persentase } \\
(\%)\end{array}$ \\
\hline Laki-laki & 24 & 30 \\
\hline Perempuan & 56 & 70 \\
\hline Jumlah & 80 & 100 \\
\hline
\end{tabular}

Sumber: Data Primer Diolah 2020

Tabel 5.1 diatas menunjukkan bahwa responden penelitian adalah pembeli pada toko Zoya Jambi terdiri dari perempuan sebanyak 56 orang atau sebesar $70 \%$, sedangkan sisanya adalah laki-laki sebanyak 24 orang atau sebesar 30\%. Hal ini menunjukkan bahwa sebagain 
besar pembeli pada toko Zoya Jambi merupakan mereka yang berjenis kelamin perempuan, hal ini dapat dimaklumi dikarenakan jenis produk yang ditawarkan oleh toko Zoya Jambi merupakan produk-produk yang lebih banyak mengkedepankan produk-produk keperluan perempun.

Selanjutnya setelah melihat karakteristik pada jenis kelamin pembeli di toko Zoya, hal berikut yang akan dilihat pada karakteristik responden adalah umur, umur merupakan suatu pertimbangan yang dapat dilihat oleh seseorang untuk memilih sesuatu keputusan dan menjadi tolak ukur kematangan emosional. berdasarkan pada karakteristik umur pembeli di toko Zoya Jambi dapat dilihat pada tabel dibawah ini

2) Karakteristik Responden Berdasarkan Umur

Tabel 5.2

Karakteristik Pembeli Berdasarkan Umur

\begin{tabular}{|l|c|c|}
\hline \multicolumn{1}{|c|}{ Umur } & Responden & $\begin{array}{c}\text { Persentase } \\
(\%)\end{array}$ \\
\hline 18-40 Tahun & 51 & 63,75 \\
\hline 41-65 Tahun & 27 & 33,75 \\
\hline$>$ 65 Tahun & 2 & 2,5 \\
\hline Jumlah & 80 & 100 \\
\hline
\end{tabular}

Sumber: Data Primer Diolah 2020

Tabel 5.2 Karakteristik responden berdasarkan umur dapat diketahui sebanyak 51 orang atau sebesar $63,75 \%$ berusia dari $18-40$ tahun, sebanyak 27 orang atau sebesar 33,75\% berusia antara 41-65 tahun, sebanyak 2 orang atau sebesar 2,5\% berusia diatas 65 tahun, sebanyak 2 orang, karakteristik berdasarkan umur ini dibagi menjadi 3 kategori yaitu: Dewasa muda 18-40 tahun, dewasa menengah 41-65 tahun dan dewasa tua diatas 65 tahun.

Dari hasil yang didapati pada tabel karekterstik pembeli di toko Zoya untuk pertanyaan umur, didapati bahwa umur pembeli pada toko Zoya didominasi oleh pembeli dengan umur 1840 tahun dengan kategori dewasa muda, dapat dikatakan bahwa pada umur 18-40 tahun biasanya seseorang sedang dalam kondisi matang, baik dari sisi pendapatan maupun emosional yang terjadi pada diri mereka, termasuk didalam pemilihan selera produk pakaian yang mereka inginkan, dan dilihat dari karakteristik pembeli pada toko Zoya Jambi dapat dikatakan mereka yang membeli di toko Zoya merupakan pembeli yang mempunyai kematangan dalam kehidupannya.

3) Karakteristik Responden Berdasarkan Pekerjaan 


\section{Tabel 5.3}

Karakteristik Pembeli Berdasarkan Pekerjaan

\begin{tabular}{|l|c|c|}
\hline \multicolumn{1}{|c|}{ Jenis Pekerjaan } & Responden & $\begin{array}{c}\text { Persentase } \\
(\%)\end{array}$ \\
\hline Ibu Rumah Tangga & 25 & 31,25 \\
\hline Pelajar/Mahasiswa & 17 & 21,25 \\
\hline Karyawan (Swasta/Negeri) & 34 & 42,5 \\
\hline Wirausaha & 3 & 3,75 \\
\hline Lainnya & 1 & 1,25 \\
\hline Jumlah & 80 & 100 \\
\hline
\end{tabular}

Sumber : Data Primer Diolah 2020

Berdasarkan tabel diatas, diketahui bahwa berdasarkan jenis pekerjaan terdapat 31,25\% Ibu Rumah Tangga, 21,25\% Pelajar/Mahasiswa, 42,5\% Karyawan (Swasta/Negeri), 3,75\% Wirausaha, dan 1,25\% lainnya. Dapat dilihat bahwa presentase terbesar yaitu $42,5 \%$ dari responden yang memiliki karakteristik pekerjaan mereka yang membeli merupakan responden yang bekerja sebagai karyawan lebih mendomoinasi, dapat dikatakan bahwa toko Zoya memberikan produk-produk yang dapat diterima oleh mereka yang bekerja 4) Karakteristik Responden Berdasarkan Pendidikan

Tabel 5.4

Karakteristik Pembeli Berdasarkan Pendidikan

\begin{tabular}{|l|c|c|}
\hline Pendidikan Terakhir & Responden & $\begin{array}{c}\text { Persentase } \\
(\mathbf{\%})\end{array}$ \\
\hline SLTA & 7 & 8,75 \\
\hline Akademi & 15 & 18,75 \\
\hline Sarjana & 32 & 40 \\
\hline Lainnya & 26 & 32,5 \\
\hline Jumlah & 80 & 100 \\
\hline
\end{tabular}

Sumber : Data Primer Diolah 2020

Berdasarkan tabel diatas, diketahui bahwa berdasarkan karakteristik jenjang pendidikan terakhir, terdapat 8,75\% konsumen tamatan SLTA/Sederajat, 18,75\% Akademi (D/I, D/II, D/III), Sarjana (SI/Sederajat), 40\%, Lainnya sebesar 32,5\%. Dapat dilihat bahwa presentase terbesar yaitu 40\% dari konsumen yang memiliki jenjang pendidikan Sarjana (S1/Sederajat). Dari karakteristik pembeli pada toko Zoya Jambi, dapat diketahui bahwa dilihat dari jenjang pendidikannya didapati pembeli pada toko Zoya Jambi mempunyai jenjang pendidikan Strata 1 atau Sarjana, lebih mendominasi pada pembelian di toko Zoya Jambi. 
5) Karakteristik Responden Berdasarkan Pendapatan

Tabel 5.5

Karakteristik Pembeli Berdasarkan Pendapatan

\begin{tabular}{|c|c|c|}
\hline Pendapatan & Responden & $\begin{array}{c}\text { Persentase } \\
(\%)\end{array}$ \\
\hline$<2,600,000$ & 47 & 58,75 \\
\hline $2,600,000$ & 21 & 26,25 \\
\hline$>2,600,000$ & 12 & 15 \\
\hline Jumlah & 80 & 100 \\
\hline
\end{tabular}

Sumber : Hasil Penelitian Lapangan (Data Primer)

Berdasarkan tabel diatas, diketahui bahwa dilihat dari karakteristik responden berdasarkan pendapatan didapati bahwa, untuk responden dengan pendapatan $<2,600,000$ ada sebanyak 47 responden, dengan nilai karakteristik sebesar 58,75\%, responden dengan tingkat pendapatan sebesar 2.600 .000 ada sebanyak 21 responden dengan nilai karakteristik sebesar $26,25 \%$, sedangkan untuk responden yang berpendapatan $>2,600,000$ ada sebanyak 12 responden dengan nilai karakteristik sebesar 15\%, nilai ukur untuk pendapatan karakteristik responden berdasarkan atas pendapatan yang diukur dengan pendapatan sedang atau sama dengan $\mathrm{UMR}=2,600,000$ yang diberlakukan saat ini, pendapatan rendah atau kurang dari UMR dan pendapatan tinggi atau lebih dari UMR.

\subsubsection{Pengaruh Promosi Penjualan Pakaian Terhadap Minat Beli Pada Toko Zoya Jambi}

Setelah diketahui karakteristik pada pembeli di toko Zoya Jambi, maka selanjutnya peneliti akan menjawab perumusan masalah kedua dalam penelitian ini, yang dapat dilihat pada tabel dan pembahasan dibawah ini:

Tabel 5.6

Perhitungan Regresi Linier Sederhana Coefficients $^{a}$

\begin{tabular}{|c|c|c|c|c|c|c|}
\hline \multirow{2}{*}{\multicolumn{2}{|c|}{ Model }} & \multicolumn{2}{|c|}{ Unstandardized Coefficients } & \multirow{2}{*}{$\begin{array}{c}\text { Standardized } \\
\text { Coefficients } \\
\text { Beta }\end{array}$} & \multirow[b]{2}{*}{$\mathrm{T}$} & \multirow[b]{2}{*}{ Sig. } \\
\hline & & $\mathrm{B}$ & Std. Error & & & \\
\hline \multirow[t]{2}{*}{1} & (Constant) & 11.36 & 603.496 & & 1.019 & .001 \\
\hline & Promosi & 620 & 3.518 & .285 & 2.595 & .005 \\
\hline
\end{tabular}

a. Dependent Variable: minat beli

Persamaan rumus regresi linear sederhana dapat diperoleh hasil sebagai berikut :

$$
\mathrm{Y}=11,36+0,620 X_{1}+\mathrm{e}
$$


Nilai konstan sebesar 11,36 artinya jika tidak ada pergerakan dari faktor promosi atau sama dengan konstan, maka minat beli akan bergerak konstan sebesar 11,36\%. Nilai koefisien regresi variabel Promosi bernilai positif, yaitu 0,620 artinya setiap Promosi meningkat sebesar $1 \%$, maka akan meningkatkan minat beli sebesar $62,0 \%$ dengan asumsi variabel independen lain nilainya tetap.

Setelah didapati persamaan regresi sederhana diatas maka selanjutnya akan dibahas nilai koefisien determinasi untuk penelitian ini, dan dapat dilihat pada tabel dibawah ini

Tabel 5.3

Analisis Koefisien Determinasi Model Summary

\begin{tabular}{|c|c|c|c|c|}
\hline Model & $\mathrm{R}$ & $\mathrm{R}$ Square & $\begin{array}{c}\text { Adjusted R } \\
\text { Square }\end{array}$ & $\begin{array}{c}\text { Std. Error of the } \\
\text { Estimate }\end{array}$ \\
\hline 1 & $.785^{\mathrm{a}}$ & .851 & .960 & .02616 \\
\hline
\end{tabular}

a. Predictors: (Constant), Promosi

Koefisien determinasi digunakan untuk mengetahui seberapa besar variabilitas variabel independen dalam menjelaskan variabel dependen yang ditunjukkan oleh nilai R Square $\left(R^{2}\right)$ atau kuadrat dari R, yaitu sebesar 0,851 artinya persentase pengaruh variabel promosi terhadap minat beli pada toko Zoya Jambi sebesar 85,1\% sedangkan sisanya 14,9\% dipengaruhi oleh variabel lain.

\section{Pengujian Hipotesis}

\section{a. Uji T}

Uji T digunakan untuk mengetahui apakah secara parsial promosi berpengaruh atau tidak terhadap minat beli toko Zoya Jambi. Pengujian menggunakan tingkat signifikasi 0,05.

Hipotesis Promosi

Ho $=$ Promosi secara parsial tidak berpengaruh terhadap minat beli toko Zoya Jambi.

$\mathrm{Ha}=$ Promosi secara parsial berpengaruh terhadap minat beli toko Zoya Jambi.

Angka T hitung sebesar 2,595 dan nilai signifikasi sebesar 0,005. T tabel dapat dilihat di tabel statistik pada tingkat signifikasi 0,05 dengan $\mathrm{df}=(\mathrm{n}-\mathrm{k}-1)$ atau $80-2-1=77$, $\mathrm{T}$ tabel sebesar 1,664

Kriteria Pengujian

Jika $\mathrm{t}$ hitung $\leq \mathrm{t}$ tabel jadi Ho diterima

Jika thitung $>$ t tabel jadi Ho ditolak 
Berdasarkan signifikasi :

Jika signifikasi > 0,05 maka Ho diterima.

Jika signifikasi $<0,05$ maka Ho ditolak.

Keputusan:

Nilai T hitung $>\mathrm{T}$ tabel $(2,595>1,664)$ artinya Ho ditolak dan $H_{a}$ diterima, dengan nilai signifikansi dibawah $0,05(0,005<0,05)$ maka Ho ditolak dan $H_{a}$ diterima, jadi dapat disimpulkan bahwa promosi berpengaruh secara parsial dan signifikan terhadap minat beli toko Zoya Jambi.

\section{KESIMPILAN DAN SARAN}

Berdasarkan hasil penelitian maka kesimpulan yang dapat dikemukakan dalam penelitian ini adalah:

1..Karakteristik dari responden pembeli pada toko Zoya jambi didapati bahwa, untuk karakteristik pembeli dilihat dari jenis kelamin lebih didominasi oleh perempuan dengan angka sebesar 70\%, untuk karakteristik umur pembeli yang mendominasi berkisar antara 26-35 sebesar $40 \%$, tingkat pendidikan pembeli yang mendominasi pada tingkat pendidikan Strata 1 (S1) dengan angka sebesar 40\%, dilihat dari pekerjaan responden pembeli toko Zoya didominasi oleh mereka yang menjawab Karyawan sebagai pekerjaannya dengan angka sebesar $42,5 \%$

2. Hasil hitungan regresi sederhana untuk Promosi menunjukan bahwa Promosi mempunyai pengaruh yang Positif dan Signifikan, dengan nilai Koefisien regresi sebesar 0,620 dengan tingkat signifikansi sebesar 0,005 , artinya variabel independen pada penelitian ini yaitu promosi berpengaruh terhadap variabel dependen yang dalam hal ini adalah minat beli.

\section{DAFTAR PUSTAKA}

Alfatris, T.D. (2012). Pengaruh Harga, Promosi, Kualitas Produk, dan Kepercayaan (Trust) Terhadap Minat Beli K-Pop (Korean Pop) Album dengan Sistem Pre Order secara Online (Studi Pada Online Shop Kordo Day Shop (CORP) Semarang). Jurnal.

Annafik, A.F.(2012). Analisis Pengaruh Kualitas Produk, Harga, dan Daya Tarik Iklan Terhadap Minat Beli Sepeda Motor Yamaha (Study Kasus pada Konsumen Yamaha SS Cabang Kedungmundu Semarang). Skripsi. Universitas Diponegoro Semarang.

Akbariyeh, H. (2015). A Study of Factors Affecting on Customers Purchase Intention (Case Study: the Agencies of Bono Brand Tile in Tehran). Journal of Multidisciplinary Engineering Science and Technology vol.4, 32-42. 
Arumsari, D. (2012). Analisis Pengaruh Kualitas Produk, Harga, dan Promosi Terhadap Keputusan Pembelian Air Minum Dalam Kemasan (AMDK) Merek Aqua (Studi pada Konsumen Toko Bhakti Mart KPRI Bhakti Praja Provinsi Jawa Tengah). Skripsi. Universitas Diponegoro Semarang.

Azmi, M.F. (2012). Pengaruh Bauran Pemasaran Terhadap Keputusan Pembelian (Survei pada Mahasiswa yang Menggunakan Notebook Asus di Universitas Brawijaya). Jurnal Vol 28, No 1. 175-184.

Basu, S., \& Irawan. (2001). Manajemen Pemasaran Modern. Yogyakarta: Liberty.

Chi et al., (2009). The Influences of Perceived Value on Consumer Purchase Intention: The Moderating Effect of Advertising Endorser. Journal.

Dama, D. (2016). Analisis Faktor-faktor yang Mempengaruhi Minat Beli Konsumen Dalam Memilih Laptop Acer di Toko Lestari Komputer Manado. Jurnal Vol. 16, No. 01.

Defriansyah D. (2016). Pengaruh Citra Merek, Harga, dan Kualitas Produk Terhadap Keputusan Pembelian Smartphone Samsung (Study Kasus Mahasiswa Universitas Sriwijaya Indralaya). 13(2), 89-101.

Febrinasari, N.D. (2015). Analisis Pengaruh International Brand Image, Promosi, Brand Awareness dan Harga Terhadap Keputusan Pembelian (Survei pada Mahasiswa S-1 Fakultas Ilmu Administrasi Universitas Brawijaya Jurusan Administrasi Bisnis Angkatan 2011-2014 yang Memiliki Smartphone Android Merek Samsung). 24 (2), 16.

Damodar, N. (2003). Ekonometrika Dasar. Jakarta: Erlangga.Hanasyha, Jalal. The Influence of Product Quality and Service Quality on Brad Leadership: Empirical Evidence from Malaysia. Jurnal. University Utara Malaysia.

Himawan, A.H. (2016). Pengaruh Kualitas Produk, Citra Merek, dan Promosi Terhadap Minat Beli Notebook Acer (Studi Kasus pada Mahasiswa Universitas Negeri Yogyakarta). Skripsi. Universitas Negeri Yogyakarta.

Kuang. H.C. (2008). The Influences of Advertising Endorser, Brand Image, Brand Equity, Price Promotion, on Purchase Intention- The Mediating Effect of Advertising.

Muhammad, S. (2015). Pengaruh Promosi, Harga, dan Kualitas Produk Terhadap Minat Beli Konsumen Kerudung Rabbani. Jurnal. Vol 5, No 1. 20-27. 